\title{
PERANCANGAN SISTEM INFORMASI MANAJEMEN KEGIATAN SIVITAS AKADEMIKA UNIVERSITAS TERBUKA
}

\author{
Andri Suryadi \\ Sistem Informasi, Fakultas Sains dan Teknologi, Universitas Terbuka \\ Universitas Terbuka Jalan Cabe Raya, Pondok Cabe, Pamulang, Tangerang Selatan 15418, Banten - \\ Indonesia \\ Email: andri.suryadi@ecampus.ut.ac.id
}

(Diterima: 19 September 2019, direvisi: 28 Desember 2019, disetujui: 29 Desember 2019)

\begin{abstract}
In the industrial era of 4.0, the development of information technology is very fast. Several countries in the world had been competing with information technology. The role of information technology, especially information systems is needed very much in everyday life. A good management information system is an information system that had been able to espouse the continuation of the organization. Due to the fact that, the Open University also needs the information systems. There had been several problems occur at the Open University, one of them was the overlapping activities of several work units. It occurred because each unit has its own agenda without knowing the agenda of the other units. Therefore, it was necessary to construct a management information system that can provide information on activities in each work unit. Before the management information system was constructed, a design was needed to ease the process of creating management information systems application for the activities of Open University. Therefore, the purpose of this study was to design an activity management information system at the Open University using a structured model. The structured model is a derivative of structured programming used at the Open University so this model is very compatible to be used. The results of this structured model were architectural, data, interface and procedural design.
\end{abstract}

Keywords: design, management information systems, academic community activities

\begin{abstract}
ABSTRAK
Di era industri 4.0 sekarang ini, perkembangan teknologi informasi dirasakan sangat cepat. Berbagai negara didunia berlomba-lomba untuk dapat bersaing dalam bidang teknologi informasi. Peran teknologi informasi khususnya sistem informasi pada saat ini sangat diperlukan dalam kehidupan sehari-hari. Sistem informasi manajemen yang baik adalah sistem informasi yang dapat mendukung terhadap jalannya organisasi. Sama halnya dengan Universitas Terbuka dukungan sistem informasi menjadi hal yang sangat penting. Terdapat beberapa masalah yang terjadi di Universitas Terbuka salah satunya adalah saling tumpang tindih kegiatan dari berbagai unit kerja. Tumpang tindih terjadi dikarenakan setiap unit mempunyai agenda masing-masing tanpa mengetahui agenda dari unit yang lainnya. Oleh karena itu perlu dibangun sebuah sistem informasi manajemen yang dapat memberikan informasi kegiatan pada masing-masing unit kerja. Sebelum dibangun sistem informasi manajemen perlu adanya perancangan terlebih dahulu untuk memudahkan dalam proses pembuatan aplikasi sistem informasi manajemen kegiatan di Universitas Terbuka, maka tujuan penelitian ini merancang sebuah sistem informasi manajemen kegiatan di Universitas Terbuka menggunakan model terstruktur. Model terstruktur merupakan turunan dari pemrograman terstuktur yang digunakan di Universitas Terbuka sehingga model ini sangat cocok digunakan. Hasil dari model terstruktur ini berupa perancangan arsitektural, perancangan data, perancangan antar muka dan perancangan prosedural.
\end{abstract}

Kata Kunci: perancangan, sistem Informasi manajemen, kegiatan sivitas akademika 


\section{PENDAHULUAN}

Dieraindustri 4.0 sekarang ini perkembangan teknologi informasi dirasakan sangat cepat. Berbagai negara didunia berlomba-lomba untuk dapat bersaing dalam bidang teknologi informasi [1]. Peran teknologi informasi khususnya sistem informasi pada saat ini sangat diperlukan dalam kehidupan sehari-hari [2]. Sistem informasi manajemen yang baik adalah sistem informasi yang dapat mendukung terhadap jalannya organisasi [3]. Sama halnya dengan di Universitas Terbuka dukungan sistem informasi menjadi hal yang sangat penting dikarenakan Universitas Terbuka adalah sebuah Universitas yang menjalankan perkuliahan dengan menggunakan sistem jarak jauh.

Terdapat beberapa masalah yang terjadi di Universitas Terbuka salah satunya adalah saling tumpang tindih kegiatan dari berbagai unit kerja. Tumpang tindih terjadi dikarenakan setiap unit mempunyai agenda masing-masing tanpa mengetahui agenda dari unit yang lainnya. Sebagai contoh unit A dengan B dengan peserta yang sama mengikuti kegiatan yang sama dan pada waktu yang bersamaan. Hal tersebut mengakibatkan kebingungan kepada peserta sehingga dampak yang terjadi adalah kurang efektif nya kegiatan yang dilaksanakan.

Dengan adanya masalah tersebut perlu adanya solusi yang diberikan yaitu salah satunya dengan membangun sistem informasi manajemen kegiatan di Universitas Terbuka. Sistem ini dibangun sebagai panduan informasi bagi unit yang akan melaksanakan kegiatan sehingga dapat mengetahui informasi mulai jadwal kegiatan, lokasi hingga peserta dan kegiatan dapat lebih efektif. Sebelum pembuatan sebuah sistem perlu adanya perancangan terlebih dahulu. Perancangan yang akan dilakukan dalam penelitian ini menggunakan model tersruktur [4].

\section{TINJAUAN PUSTAKA}

Konsep pendekatan terstruktur (structured approach) dimulai sejak tahun 1970. Pendekatan terstruktur dilengkapi dengan alat-alat (tools) dan teknik-teknik (techniques) yang dibutuhkan dalampengembangan sistem, sehingga hasil akhir dari sistem yang dikembangkanakan didapatkan sistem yang strukturnya didefinisikan dengan baik [5]. Komponen model terstruktur ini menggunakan DFD (data flow diagram) yang terdiri dari: (1). external entity (kesatuan luar) atau boundary (batas sistem) (2) data flow (arus data); (3) Process (proses) (4). data store (simpanan data).

DFD sering digunakan untuk menggambarkan suatu sistem yang telah ada atau sistem baru yang akan dikembangkan secara logika tanpa mempertimbangkan lingkungan fisik dimana data tersebut mengalir (misalnya lewat telpon, surat dan sebagainya) atau lingkungan fisik dimana data tersebut akan disimpan (misalnya file kartu, microfile, harddisk, tape, diskette dan lain sebagainya). DFD merupakan alat yang dapat menggambarkan arus data di dalam sistem dengan terstruktur dan jelas. Lebih lanjut DFD juga merupakan dokumentasi dari sistem yang baik [6].

Hal pertama dalam membangun sebuah rancangan sistem informasi adalah analisis sistem yang meliputi informasi domain yang dibutuhkan, kebutuhan fungsonal, kegunaan dan tampilan [7]. Analisis sistem atau sering disebut dengan system requirements dibedakan menjadi dua bagian yaitu kebutuhan fungsional dan kebutuhan non fungsional [8]. Kebutuhan fungsional adalah kebutuhan yang berdasarkan pada fungsi-fungsi sistem[9] sedangkan kebutuhan non fungsional adalah batasan layanan atau fungsi yang ditawarkan sistem seperti Batasan waktu, Batasan pengembangan proses, standarisasi, infrastruktur pengembangan perangkat lunak [10]. Pada penelitian ini kebutuhan fungsional sistem informasi manajemen kegiatan adalah kebutuhan akan fungsi dari sistem sedangkan kebutuhan non fungsional adalah kebutuhan tools pengembangan sistem.

Dalam penelitian ini akan dibuatkan sebuah rancangan sistem informasi mulai dari analisis sistem, dilanjutkan dengan data flow diagram, kemudian pembuatan database dan terkahir pembuatan rancangan tampilan. Dari keempat komponen tersebut merupakan hasil dari penelitian ini akan dijadikan sebagai bahan untuk tahap implementasi atau tahap pembuatan aplikasi menggunakan bahasa pemograman berbasis web [7]. 


\section{METODE PENELITIAN}

Metode penelitian dalam penelitian ini terdapat beberapa tahapan, mulai dari analisis kebutuhan sistem, desain sistem menggunakan model rancangan terstruktur yang terdiri dari data flow diagram, rancangan basis data dan rancangan tampilan [16]. Dari tahapan metodologi ini akan menghasilkan sebuah rancangan yang siap diimplementasikan untuk membangun sebuah aplikasi. Dalam penelitian ini pendekatan yang digunakan adalah pendekatan dengan model terstruktur yang mana merupakan bagian dari tahapan pengembangan perangkat lunak metode waterfall [17].

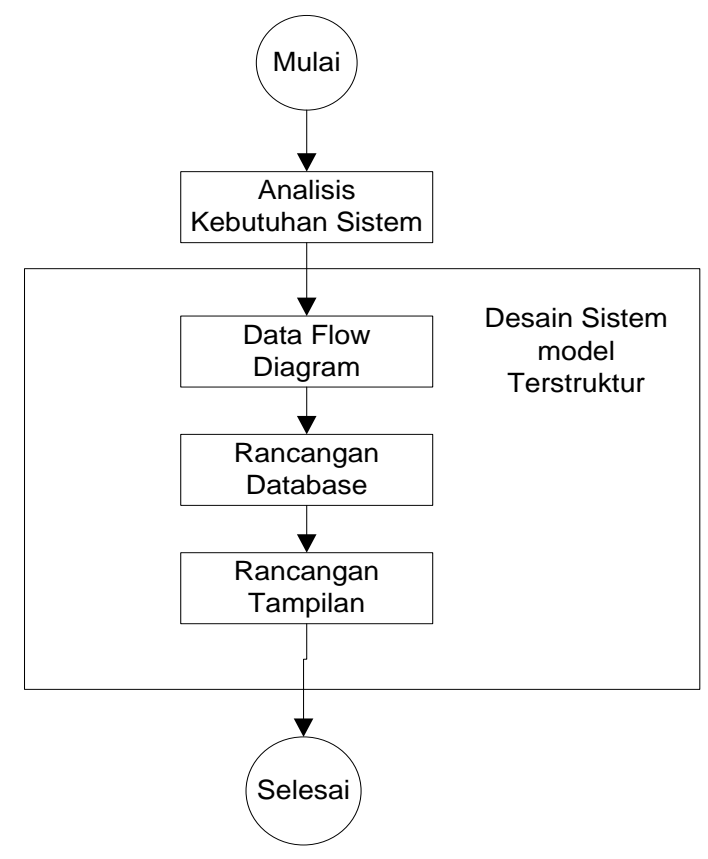

\section{a. Analisis sistem}

\section{Gambar 1 Pendekatan terstruktur}

Tahapan analisis sistem ini merupakan tahapan mengenali sistem yang akan dibangun. Pada tahapan ini teknik yang digunakan adalah teknik observasi partisipatoris dimana peneliti memposisikan sebagai partisipan sebagaimana orang yang sedang diteliti [18]. Hasil dari analisis ini akan dituangkan kedalam kebutuhan fungsional dan non fungsional.

b. Data flow diagram

Setelah sistem dianalisis terkait dengan kebutuhan, selanjutnya menggambarkan DFD (data flow diagram). Kebutuhan sistem yang sudah ada dituangkan ke dalam data flow diagram.

c. Rancangan database

Kemudian tahapan berikutnya adalah merancang database. Database ini merupakan tempat penyimpanan data sesuai dengan kebutuhan sistem yang akan dibuat. Rancangan database digambarkan dalam bentuk ERD (entity relationship diagram).

d. Rancangan tampilan

Tahapan ini adalah rancangan tampilan sistem. Tampilan ini merupakan gambaran kasar dari sistem yang akan dibuat sebagai alat bantu untuk diberikan kepada pembuat aplikasi.

\section{HASIL DAN PEMBAHASAN}

\subsection{Analisis}

Analisis kebutuhan sistem informasi manajemen kegiatan sivitas akademika di Universitas Terbuka dibagi menjadi 2 yaitu kebutuhan fungsional dan kebutuhan non fungsional. Kebutuhan fungsional yaitu kebutuhanakan sistem dilihat dari fungsi sistem yang akan dibangun sedangkan kebutuhan non fungsional adalah kebutuhan infrastruktur:

a. Kebutuhan fungsional 
1) Sistem Kegiatan ini dibangun berbasis web

2) Sistem kegiatan ini dapat diinput oleh beberapa pengguna dalam hal ini staf unit kerja yang merupakan pelaksana kegiatan

3) Sistem kegiatan ini dapat dilihat oleh seluruh sivitas akademika Universitas Terbuka (pengguna)

4) Untuk memasukan data terhadap sistem dibutuhkan login khusus dari staf sivitas akademika, sedangkan pengguna tidak perlu login.

5) Staf maupun pengguna dapat melihat laporan dari seluruh kegiatan yang terjadi

6) Data kegiatan yang dimasukan adalah informasi kegiatan, waktu dimulai, waktu selesai, tempat kegiatan, nama kegiatan, unit penyelenggara dan peserta.

b. Kebutuhan non fungsional

1) Sistem ini berjalan di server apapun

2) Sistem ini menggunakan bahasa pemograman web

3) Sistem ini menggunakan database my $s q l$

4) Dapat diakses oleh browser apapun dikomputer pengguna

\subsection{Desain}

\section{a. Data Flow Diagram (DFD)}

Pada desain sistem informasi manajemen kegiatan ini terdapat beberapa tahapan yang akan dibuat. Diawali dengan data flow diagram. Data flow diagram terdiri dari contex diagram dan data flow diagram level 0. Contex diagram pada sistem informasi manajemen kegiatan dapat dilihat pada Gambar 2.

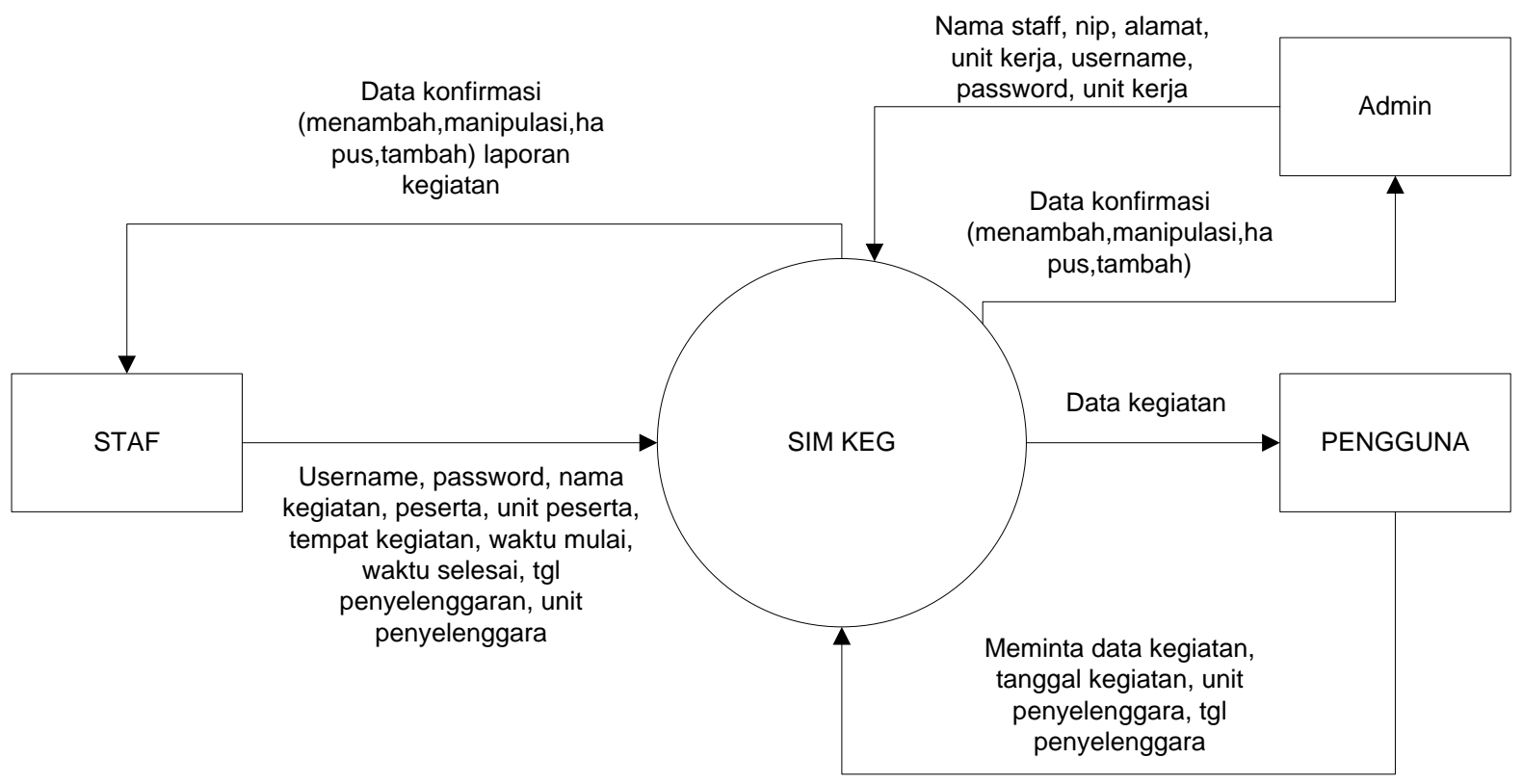

Gambar 2 Contex diagram

Contex Diagram pada sistem ini terdapat dua pengguna yang terlibat. yaitu staf, bukan staf (sivitas akademika) dan administrator sebagai kendali sistem. Pada level staf terdapat beberapa data yang dikirimkan ke sistem diantaranya username, password, nama kegiatan, peserta unit, tempat kegiatan, waktu mulai, waktu selesai, tgl penyelenggara dan unit penyelenggara sedangkan data yang diterima dari sistem adalah data konfirmasi (menambah data, manipulasi, hapus dan tambah), laporan kegiatan. Pada level pengguna (bukan staf) dapat meminta data kegiatan, tanggal kegiatan, unit penyelenggara dan tanggal penyelenggara sedangkan data yang diterima dari sistem berupa data kegiatan yang diminta. Level administrator data yang dimasukan berupa nama staf, nip, alamat, unit kerja, username, password. Sedangkan data yang diterima dari sistem berupa data konfirmasi dari tambah data, manipulasi, hapus, tambah dan laporan kegiatan. 
Dari Contex Diagram akan di breakdown menjadi level 0 yang menggambarkan data secara lebih detail lagi. Berikut Gambaran DFD Level 0:

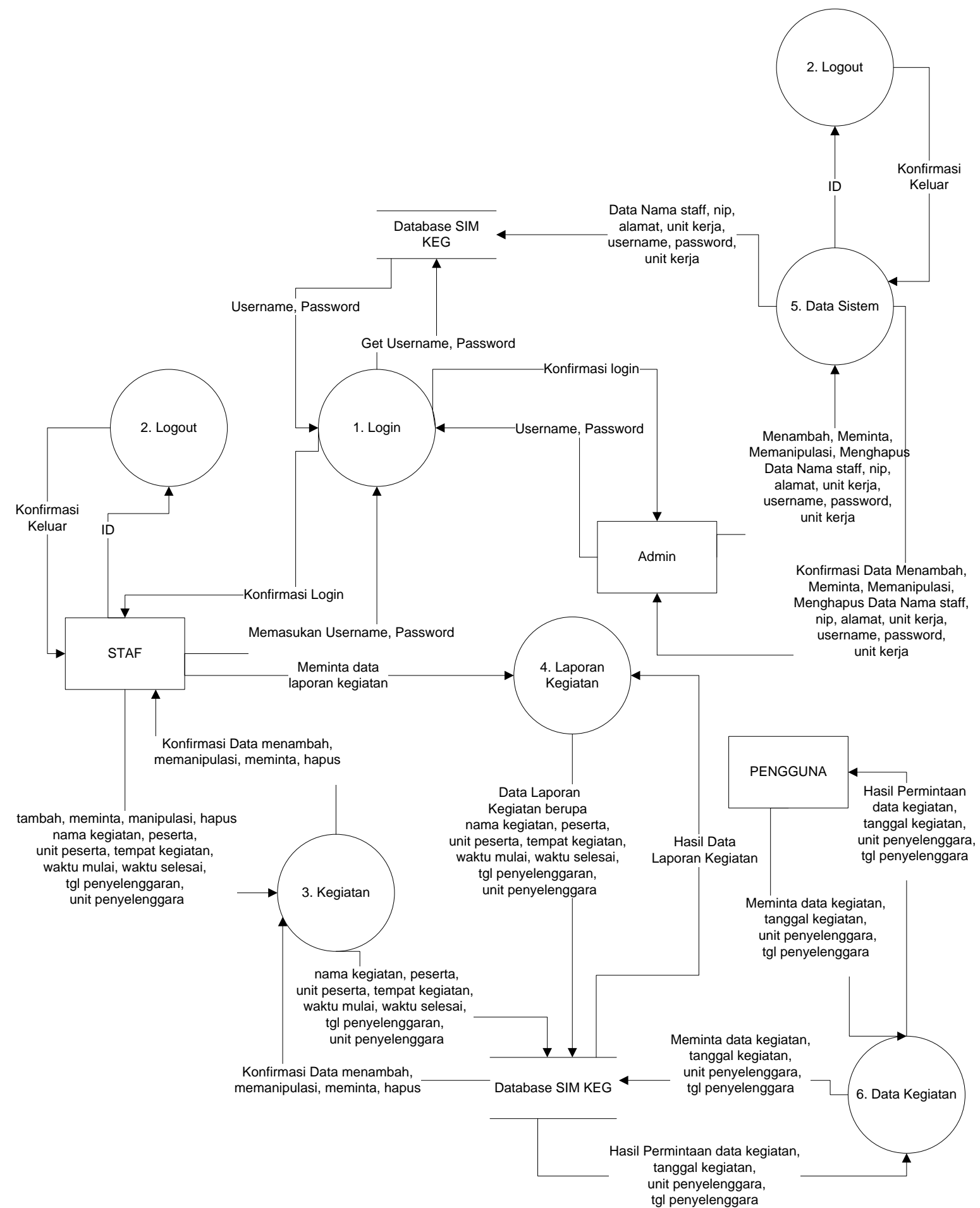

Gambar 3 DFD level 0

Data flow diagram level 0 merupakan turunan dari contex diagram. Terdapat beberapa proses yang terjadi pada data flow diagram level 0 ini. Proses tersebut adalah proses 1 Login, proses 2 Logout, Proses 3 Kegiatan, proses 4 laporan kegiatan, proses 5 data sistem dan proses 6 data kegiatan. Pada proses 1 Login data pengguna (admin dan staf) yang dikirimkan adalah username dan password kemudian data tersebut dikirimkan ke database kemudian data kembali dikirimkan kembali kepada staf. Pada proses 2 Logout data (admin dan staf) mengirimkan ID untuk dilakukan penghapusan 
session login supaya data dipakai pada saat login tidak dapat dipakai kembali. Pada proses 3 Kegiatan, staf melakukan (tambah, meminta, manipulasi, hapus) data nama kegiatan, peserta, unit peserta, tempat kegiatan, waktu mulai, waktu selesai, tgl penyelenggaran dan unit penyelenggara. Kemudian data tersebut akan disimpan kedalam database. Kemudian proses 4 laporan kegiatan, staf meminta data laporan kegiatan berupa nama kegiatan, peserta, unit peserta, tempat kegiatan, waktu mulai, waktu selesai, tgl penyelenggaran dan unit penyelenggaran. Data tersebut diminta dari database kemudian akan dikirimkan kembali sesuai dengan permintaan. Selanjutnya proses 5 data sistem, proses data sistem ini dilakukan oleh admin berupa menambah, meminta, memanipulasi, menghapus data mama staf, nip, alamat, unit kerja, username dan password. Proses terakhir yaitu proses 6 berupa proses data kegiatan yang diminta oleh pengguna bukan staf yaitu meminta data kegiatan, tanggal kegiatan, unit penyelenggara dan tgl penyelenggara.

\section{b. Perancangan Entity Relationship Diagram}

Tahapan berikutnya adalah perancangan entity realtionship diagram (ERD). Pada perancangan ERD ini terdapat beberapa macam entitas diantaranya entitas staf, info, tempat dan unit. Dapat dilihat pada gambar berikut:

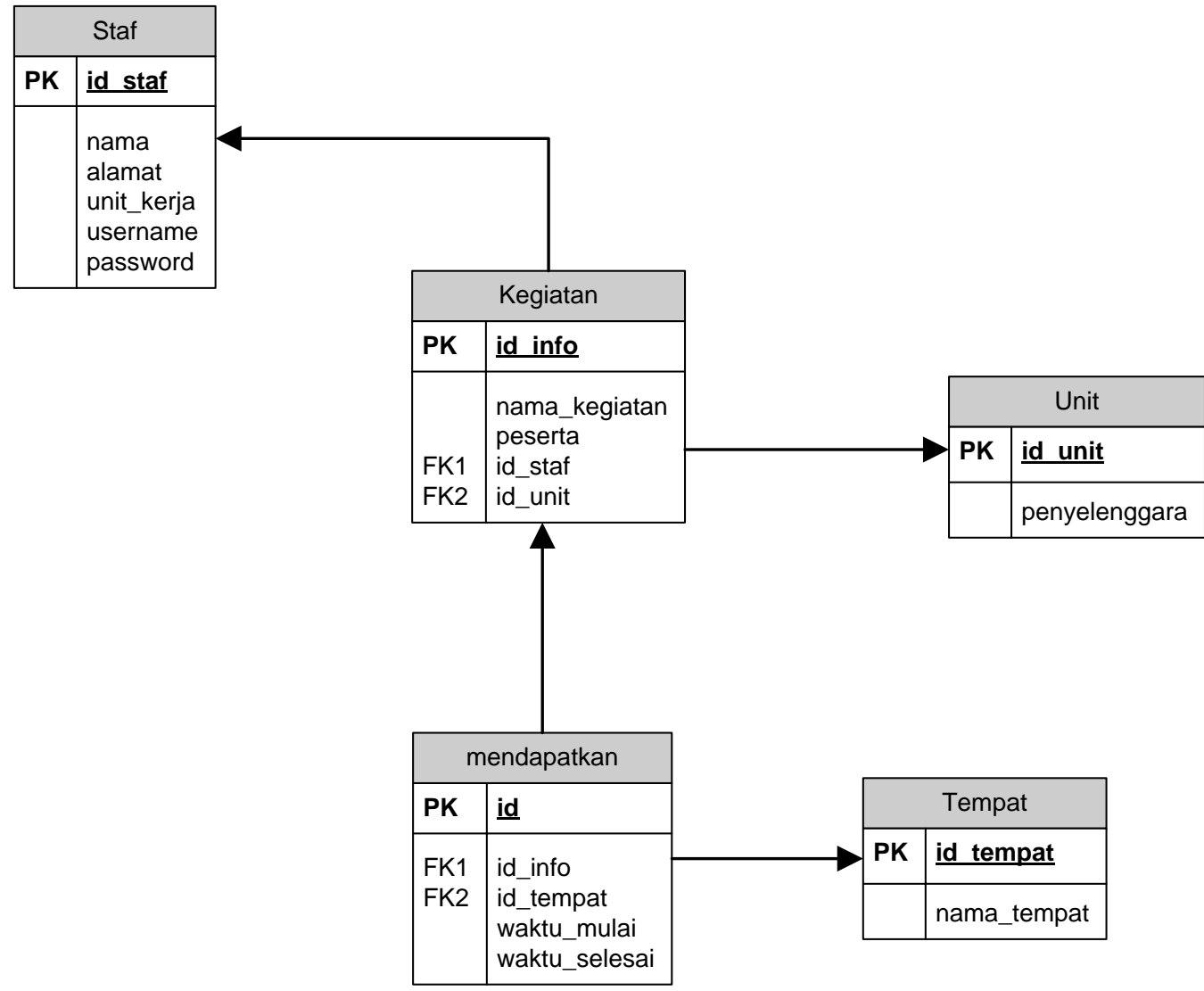

\section{Gambar 4 Rancangan ERD}

Entitas staf berelasi dengan entitas kegiatan dengan derajat kardinalitas staf adalah satu ke banyak entitas kegiatan. Kemudian entitas kegiatan berelasi dengan entitas unit dengan kardinalitas satu untuk unit dan banyak untuk kegiatan. Selanjutnya entitas kegiatan dengan entitas mendapatkan yang mana kardinalitas satu untuk entitas kegiatan dan banyak untuk entitas mendapatkan. Dan yang terkahir entitas mendapatkan dengan entitas tempat. Satu untuk entitas tempat dan banyak untuk entitas mendapatkan. 
Untuk melihat detail dari setiap entitas berikut disajikan dalam bentuk tabel beserta dengan tipe datanya. Dimulai dengan tabel 1 yaitu tabel staf yang terdiri dari beberapa atribut seperti id_staf (number primary key), nama (char 20), alamat (varchar 200), unit_kerja (char 10), username (char 10) dan password (varchar 200). Berikut Gambar detail dari tabel staf.

\begin{tabular}{|l|l|l|c|c|}
\hline \multicolumn{1}{|c|}{ Physical Name } & \multicolumn{1}{c|}{ Data Type } & Req'd & PK \\
\hline id_staf & Large Signed Number & $\square$ & $\square$ \\
\hline nama & SBCS Char(20) & $\square$ & $\square$ \\
\hline & SBCS VarChar(200) & $\square$ & $\square$ \\
\hline alamat & SBCS Char(10) & $\square$ & $\square$ \\
\hline unit_kerja & SBCS Char(10) & $\square$ & $\square$ \\
\hline username & SBCS Char & $\square$ & $\square$ \\
\hline password & SBCS VarChar(200) & $\square$ & $\square$ \\
\hline
\end{tabular}

Gambar 5 Tabel Staf

Selanjutnya adalah tabel kegiatan yang terdiri dari id_info (number primary key), nama_kegiatan (varchar 200), peserta (char 20), id_staf (number foreign key) dan id_unit (number foreign key).

\begin{tabular}{|l|l|l|c|c|}
\hline \multicolumn{1}{|c|}{ Physical Name } & \multicolumn{1}{c|}{ Data Type } & Req'd & PK \\
\hline id_info & Large Signed Number & $\square$ & $\square$ \\
\hline nama_kegiatan & SBCS VarChar(200) & $\square$ & $\square$ \\
\hline peserta & SBCS Char(20) & $\square$ & $\square$ \\
\hline id_staf & Large Signed Number & $\square$ & $\square$ \\
\hline id_unit & Large Signed Number & $\square$ & $\square$ \\
\hline
\end{tabular}

Gambar 6 Tabel kegiatan

Kemudian tabel Unit pada gambar 7. Tabel unit ini merupakan unit-unit yang menyelenggarakan kegiatan yang terdiri dari id_unit (number primary key) dan penyelenggara (char 20).

\begin{tabular}{|l|l|l|c|c|}
\hline & \multicolumn{1}{|c|}{ Physical Name } & \multicolumn{1}{c|}{ Data Type } & Req'd & PK \\
\hline id_unit & Large Signed Number & $\square$ & $\square$ \\
\hline penyelenggara & SBCS Char(20) & $\square$ & $\square$ \\
\hline
\end{tabular}

Gambar 7 Tabel Unit

Tabel berikutnya adalah tabel mendapatkan dapat dilihat pada gambar 8 . Tabel ini merupakan tabel yang menghubungkan antara entitas kegiatan dengan entitas tempat. Tabel mendapatkan ini terdiri dari id (number primary key), id_info (number foreign key), id_tempat (number foreign key), waktu_mulai (date time) dan waktu_selesai (date time).

\begin{tabular}{|l|l|l|c|c|}
\hline \multicolumn{1}{|c|}{ Physical Name } & \multicolumn{1}{c|}{ Data Type } & Req'd & PK \\
\hline id & Large Signed Number & $\square$ & $\square$ \\
\hline id_info & Large Signed Number & $\square$ & $\square$ \\
\hline & id_tempat & Large Signed Number & $\square$ & $\square$ \\
\hline waktu_mulai & Small Date \& Time & $\square$ & $\square$ \\
\hline waktu_selesai & Small Date \& Time & $\square$ & $\square$ \\
\hline
\end{tabular}

Gambar 8 Tabel mendapatkan

Tabel terakhir adalah tabel tempat yang dapat dilihat pada gambar 9. Tabel ini terdiri dari id_tempat (number primary key) dan nama_tempat (char 20).

\begin{tabular}{|l|l|l|c|c|}
\hline & \multicolumn{1}{|c|}{ Physical Name } & \multicolumn{1}{c|}{ Data Type } & Req'd & PK \\
\hline id_tempat & Large Signed Number & $\square$ & $\square$ \\
\hline nama_tempat & SBCS Char(20) & $\square$ & $\square$ \\
\hline
\end{tabular}

\section{Gambar 9 Tabel tempat}

Andri Suryadi, Perancangan Sistem Informasi Manajemen Kegiatan Sivitas Akademika Universitas Terbuka 


\section{c. PerancanganTampilan}

Tahapan terkahir adalah perancangan tampilan sistem. Perancangan tampilan ini terdiri dari lima buah tampilan yang akan disajikan yaitu tampilan utama, tampilan info, tambah info, tampilan staf dan tambah_staf. Berikut tampilan yang disajikan.

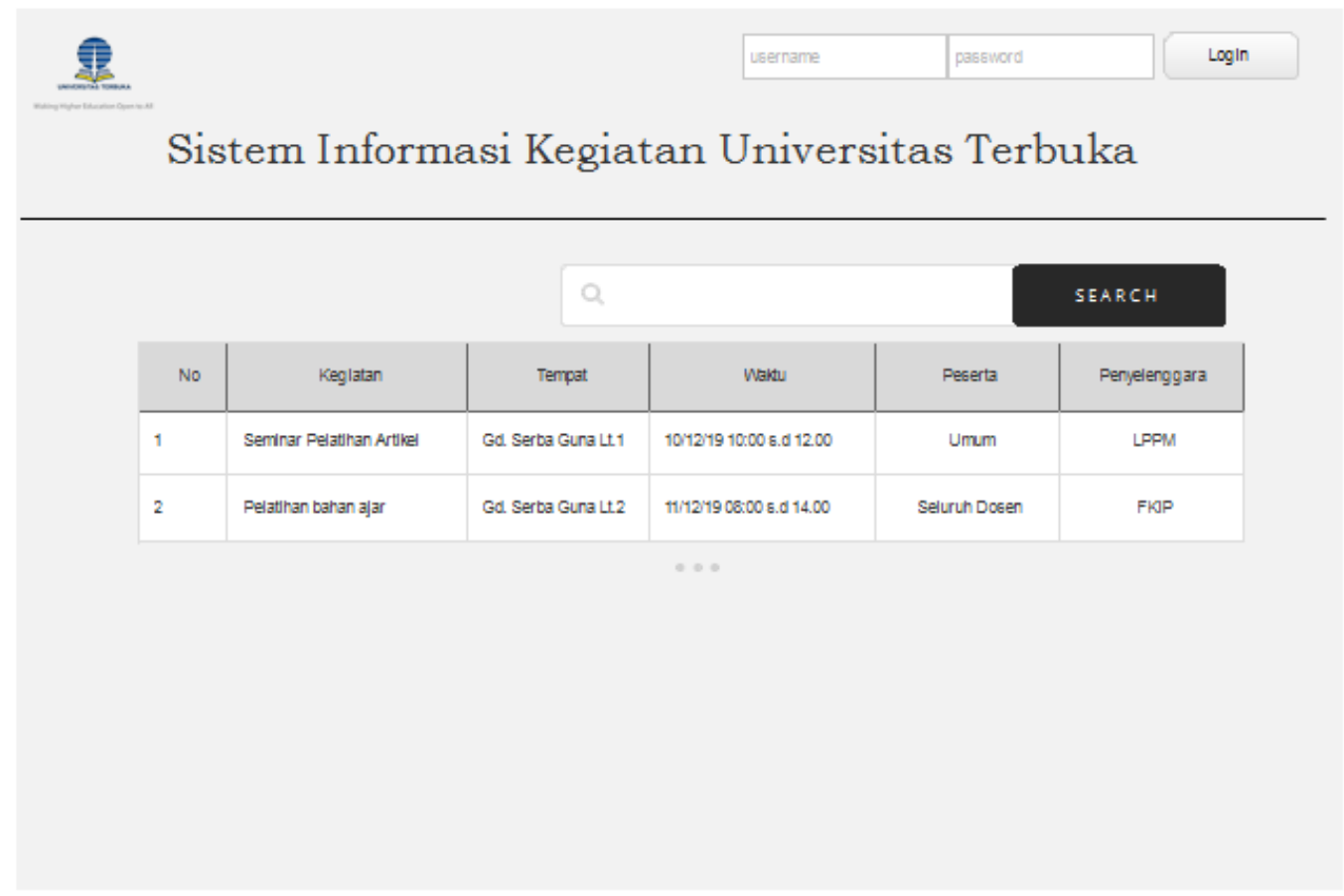

\section{Gambar 10 Tampilan utama}

Tampilan utama dapat dilihat pada gambar 10 yang merupakan tampilan awal ketika sistem informasi kegiatan ini diakses. Tampilan ini menyajikan informasi kegiatan dari yang telah diinputkan oleh staf unit. Berikut penjelasan dari tampilan utama

1) Login berupa tombol yang terdapat dua inputan yaitu username dan password.

2) Header akan menampilkan gambar disertai dengan logo sistem, logo universitas.

3) Tampilan informasi berisi tentang informasi kegiatan di Universitas Terbuka.

4) Tombol pencarian untuk mencari informasi kegiatan

Tampilan utama hanya berisikan informasi-informasi kegiatan yang dibutuhkan oleh pengguna. Informsi yang disajikan dapat diketahui tanpa harus login terlebih dahulu.

Selanjutnya adalah tampilan halaman staf setelah melakukan login kedalam sistem. Tampilan halaman staf setelah login tersebut dapat dilihat pada Gambar 11 berikut. 


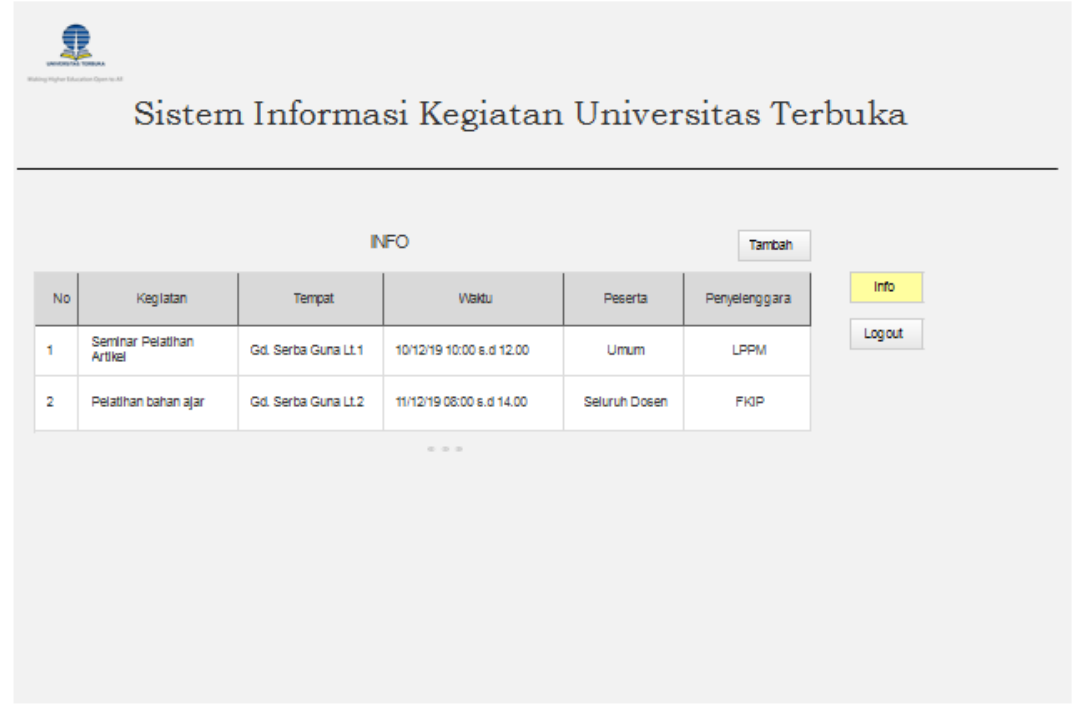

Gambar 11 Tampilan info

Tampilan info merupakan tampilan untuk staf unit setelah melakukan login. Beberapa tampilan sama dengan halaman utama seperti header. Tambahan pada tampilan ini adalah sebagai berikut:

1) Menu pada posisi kanan merupakan menu-menu yang dapat dipilih oleh staf unit.

2) Tombol tambah merupakan tombol jika ingin menambah informasi kegiatan

3) Informasi kegiatan merupakan data informasi yang telah dimasukan ditambah dengan fitur edit dan hapus.

Selanjutnya adalah menu tambah kegiatan. Menu ini berfungsi untuk menambah kegiatan oleh staf. Berikut Gambar 12 menggambarkan tambah kegiatan:

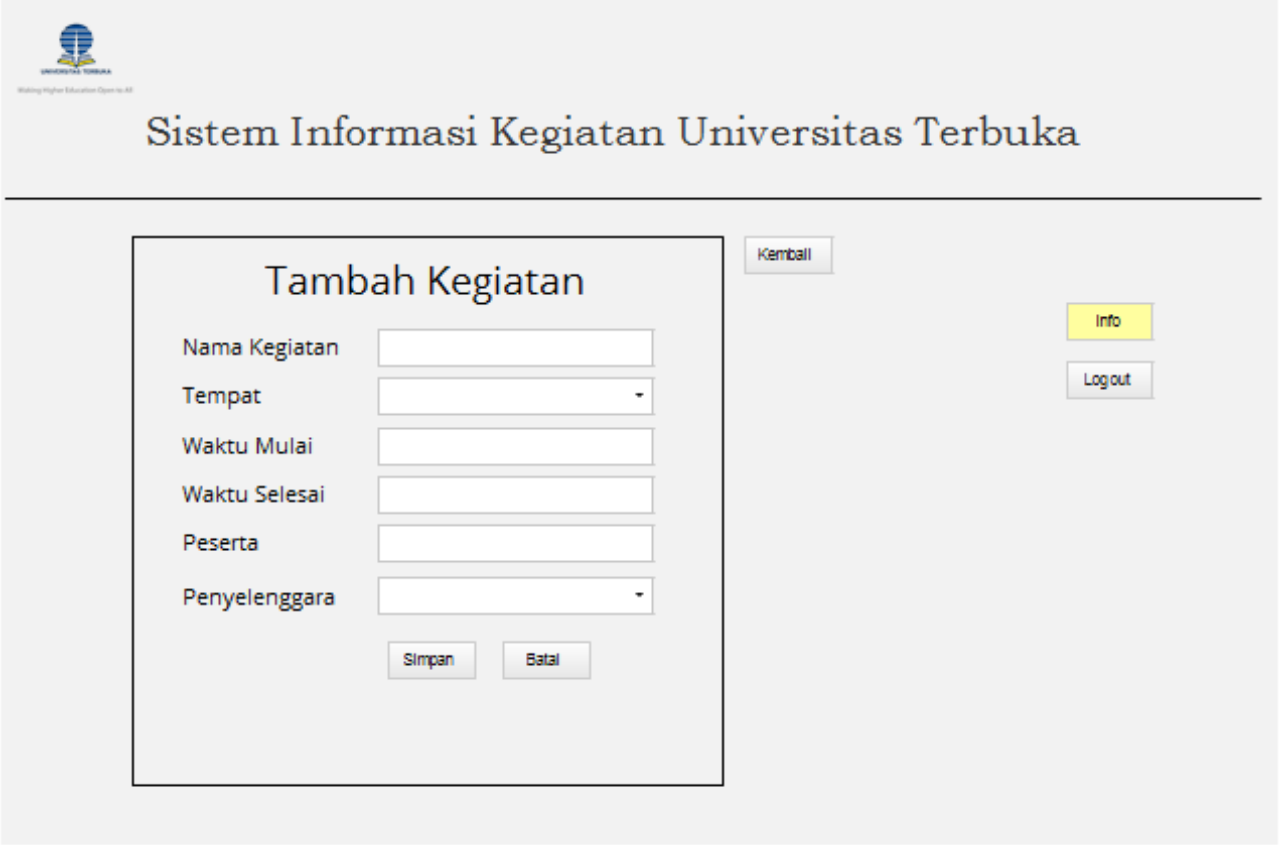

\section{Gambar 12 Tampilan tambah kegiatan}

Ketika user unit telah menekan tombol tambah, maka tampilan yang terjadi adalah tampilan tambah kegiatan. Penjelasan dari tampilan tambah kegiatan ini adalah sebagai berikut:

1) Menu sama dengan tampilan info.

2) Tombol kembali berfungsi untuk kembali ke halaman info.

Andri Suryadi, Perancangan Sistem Informasi Manajemen Kegiatan Sivitas Akademika Universitas Terbuka 
3) Tabel tambah data berupa kegiatan, tempat, waktu mulai, waktu selesai dan peserta dan penyelenggara.

4) Tombol submit untuk menyimpan data

Untuk memudahkan staf dalam memasukan data kegiatan maka data master seperti tempat, pengguna dan unit penyelenggara harus dimasukan terlebih dahulu kedalam database. Tugas ini dilakukan oleh seorang administrator. Berikut tampilan halaman administrator dalam memasukan data master. Gambar 13 adalah tampilan awal administrator yang dapat dilihat sebagai berikut:

Pada Gambar 13 administrator dapat melihat tampilan awal dengan penjelasan sebagai berikut:

1) Informasi staf dapat dilihat di halaman depan

2) Tombol Tambah berfungsi sebagai menu untuk menambah staf

3) Tombol Tempat berfungsi untuk menghubungkan ke halaman tempat

4) Tombol Unit berfungsi untuk menghubungkan ke halaman unit

5) Tombol Logout untuk keluar

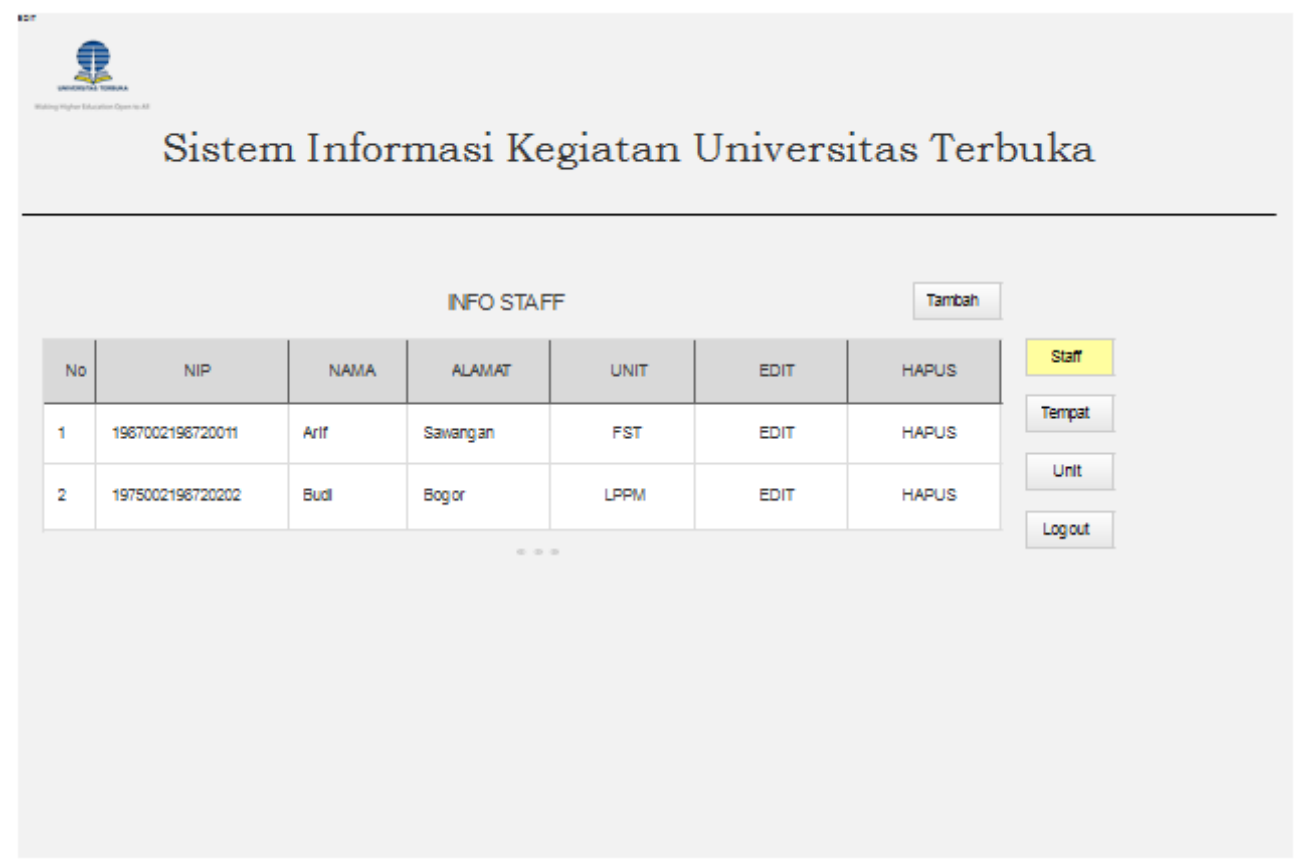

\section{Gambar 13 Tampilan info staf}

Menu administrator selanjutnya adalah tambah staf. Tampilan tambah staf ini untuk menambahkan staf yang akan mengelola kegiatan. Gambaran menu tambah staf dapat dilihat pada Gambar 14 berikut: 


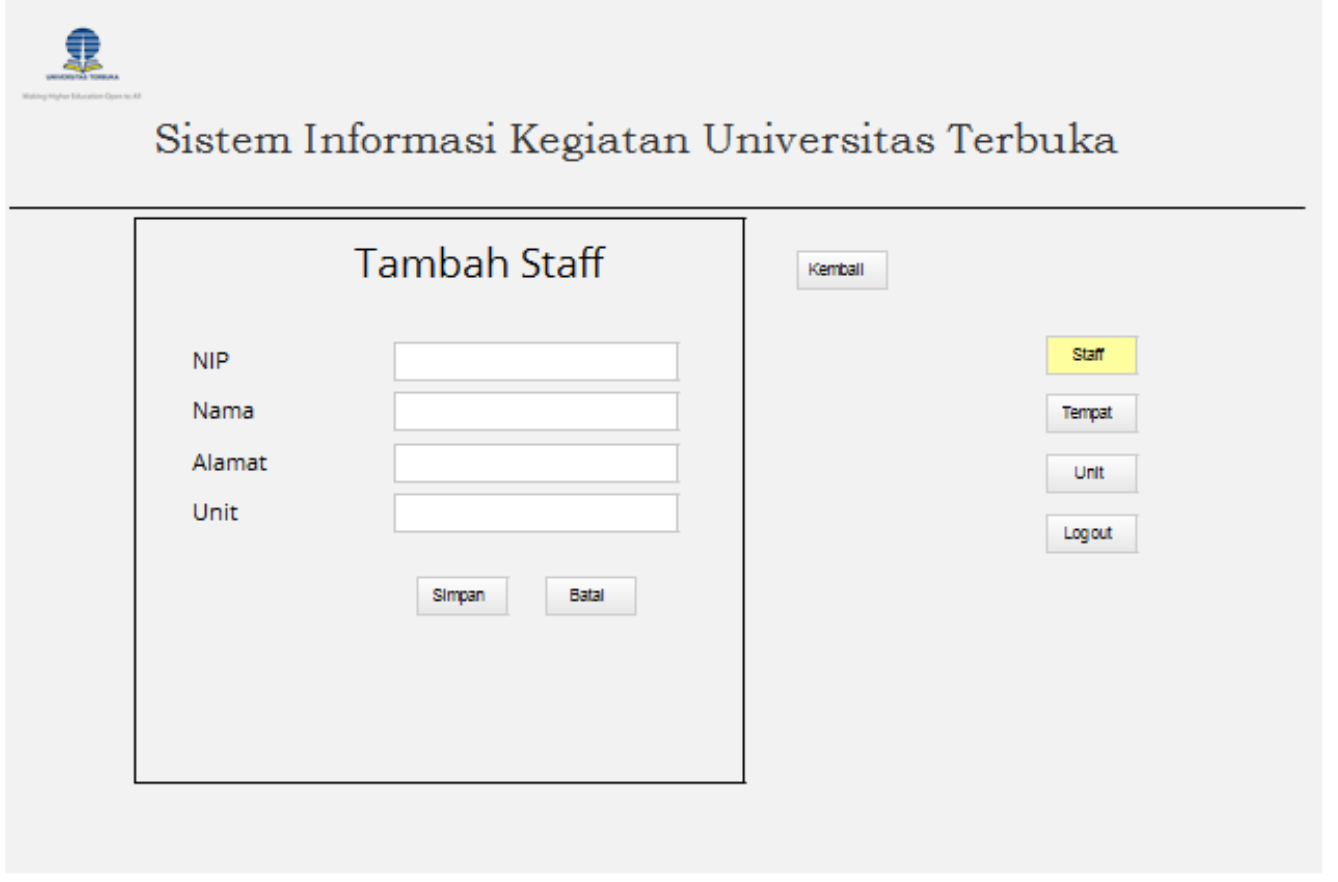

Gambar 14 Tambah staf

Berikut penjelasan pada tampilan tambah staf:

1) Data yang dapat diinputkan pada tambah staf adalah nip, nama, alamat, unit.

2) Tombol simpan untuk menyimpan data dan tombol batal untuk membatalkan penyimpanan

3) Tombol kembali untuk kembali ke halaman staf

4) Tombol Tempat berfungsi untuk menghubungkan ke halaman tempat

5) Tombol Unit berfungsi untuk menghubungkan ke halaman unit

6) Tombol Logout untuk keluar

Menu selanjutnya pada administrator adalah menu tempat. Menu tempat ini sebagai tempat dimana kegiatan diselenggakan. Untuk melihat gambaran pada menu tempat ini dapat dilihat pada Gambar 15.

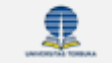

Sistem Informasi Kegiatan Universitas Terbuka

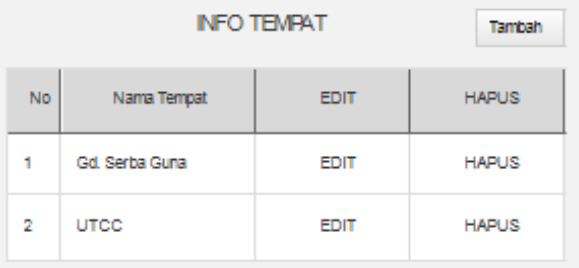




\section{Gambar 15 Tampilan tempat}

Pada tampilan tempat ini terdapat beberapa menu diantaranya:

1) Informasi tempat dapat dilihat pada bagian depan

2) Tombol tambah berfungsi sebagai tambah tempat

3) Tombol staf berfungsi untuk menghubungkan ke halaman staf

4) Tombol Unit berfungsi untuk menghubungkan ke halaman unit

5) Tombol Logout untuk keluar berikut.

Selanjutnya tampilan tambah staf. Tampilan tambah staf ini dapat dilihat pada gambar 16

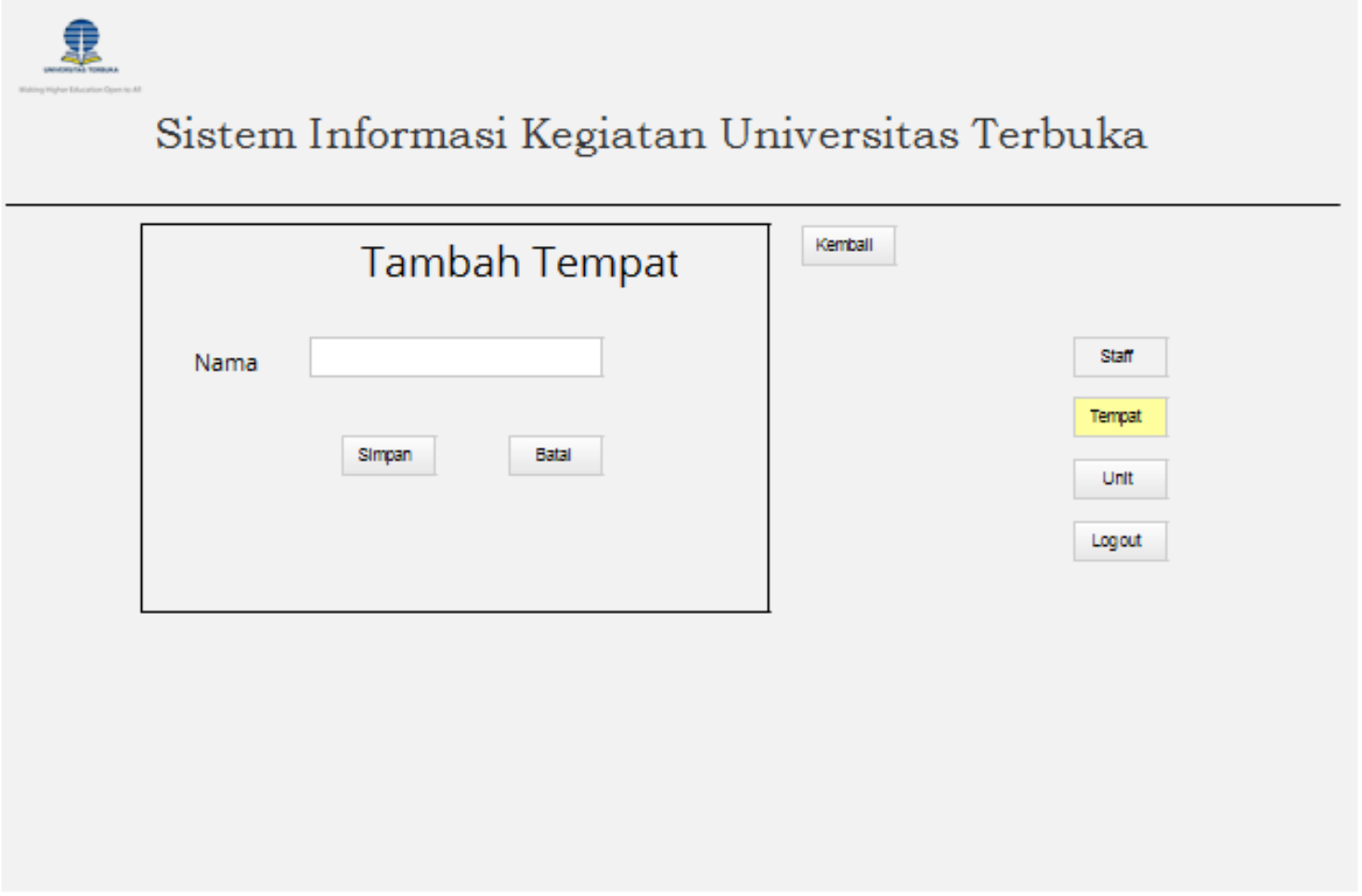

\section{Gambar 16 Tampilan tambah tempat}

Pada tampilan tambah tempat ini terdapat beberapa menu diantaranya:

1) Tempat input nama untuk menambah tambah data tempat

2) Tombol simpan untuk menyimpan data

3) Tombol batal untuk membatalkan penyimpanan

4) Tombol staf untuk menghubungkan ke halaman staf

5) Tombol tempat untuk menghubungkan ke halaman unit

6) Tombol logout untuk keluar

Tampilan berikutnya adalah tampilan unit penyelenggara. Tampilan ini menampilkan unit-unit penyelenggara. Tampilan unit penyelenggara dapat dilihat pada gambar 17 berikut ini: 


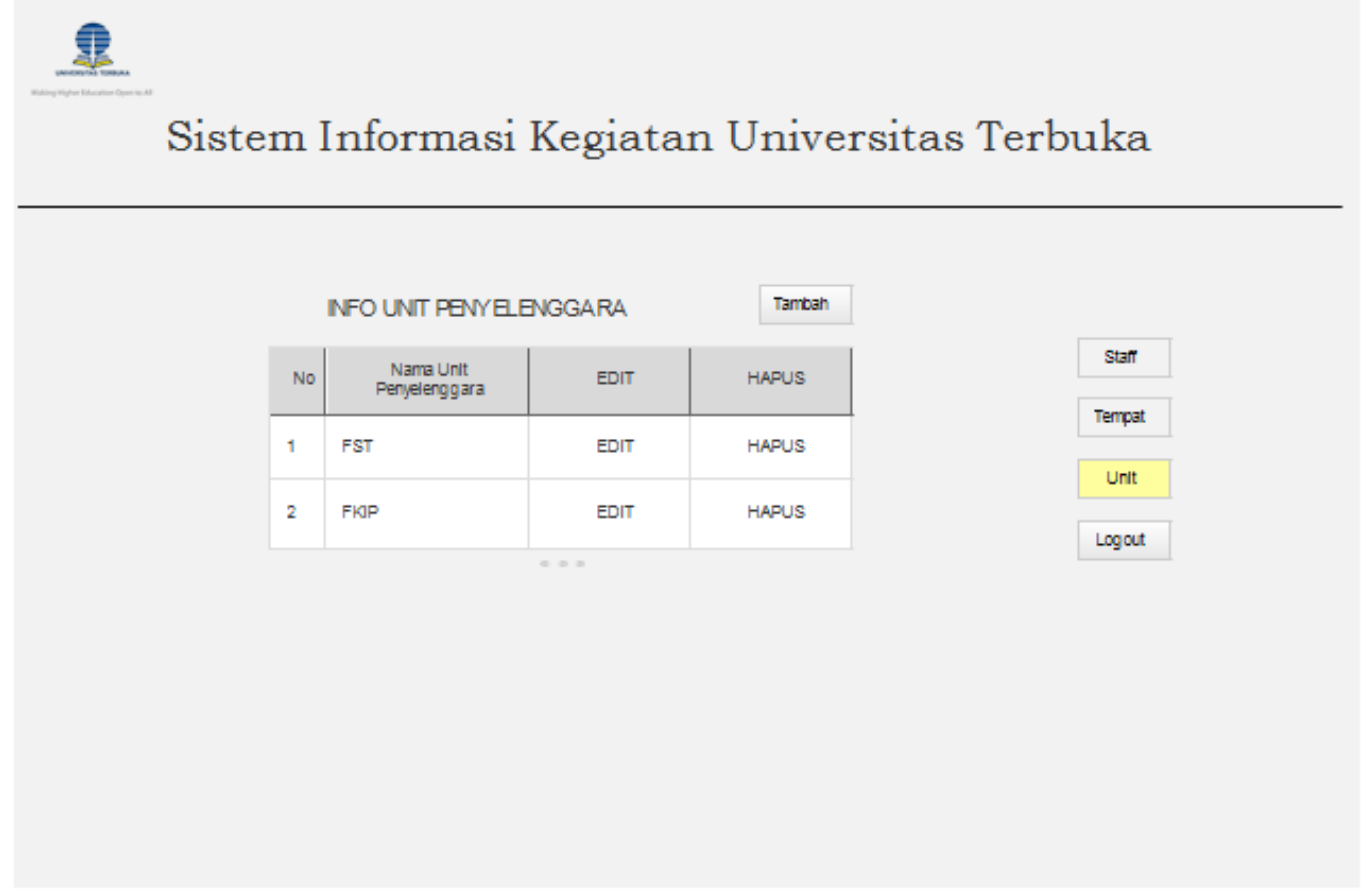

Gambar 17 Tampilan unit penyelenggara

Pada tampilan penyelenggara beberapa hal yang dapat dilihat diantaranya:

1) Informasi unit penyelenggara

2) Tombol tambah untuk menambah unit penyelenggara

3) Tombol staf untuk menghubungkan ke halaman staf

4) Tombol Unit untuk menghubungkan ke halaman unit

5) Tombol logout untuk keluar

Terakhir adalah tampilan tambah unit penyelenggara. Tampilan ini berfungsi untuk menambah unit penyelenggara kegiatan. Tampilan ini akan digambarkan pada gambar 18:

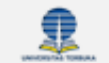

Sistem Informasi Kegiatan Universitas Terbuka

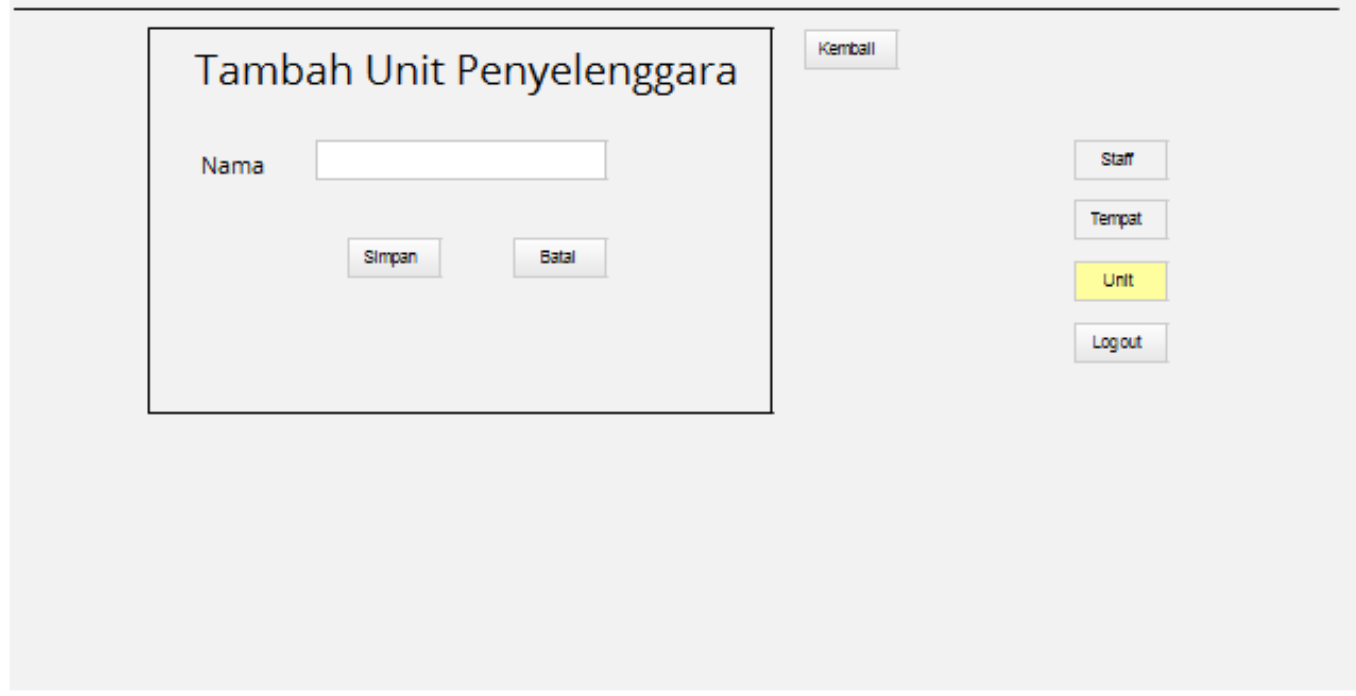




\section{Gambar 18 Tampilan tambah unit penyelenggara}

Pada tampilan unit penyelenggara terdapat beberapa hal yang dapat dilakukan diantaranya:

1) Memasukan data nama unit penyelenggara

2) Tombol simpan untuk menyimpan data

3) Tombol batal untuk membatalkan penyimpanan

4) Tombol kembali untuk kembali ke halaman unit penyelenggara

5) Tombol staf untuk menghubungkan ke halaman staf

6) Tombol tempat untuk menghubungkan ke halaman tempat

7) Tombol unit untuk menghubungkan ke halaman unit

8) Tombol logout untuk keluar

Rancangan kebutuhan aplikasi sistem ini sesuai dengan kebutuhan hasil analisis adalah sebagai berikut:

1) Bahasa pemograman yang digunakan adalah PHP guna memenuhi kebutuhan.

2) Database yang digunakan adalah mysql

3) Spesifikasi server yang dibutuhkan adalah Windows Server atau Linux dengan web server menggunakan apache.

Kesesuaian rancangan sistem ini dilihat dari sisi kesesuaian kebutuhan fungsional pada tahapan analisis. Berikut tabel kesesuaian perancangan dengan kebutuhan:

Tabel 1 Kesesuaian Kebutuhan

\begin{tabular}{|c|c|c|}
\hline No & Kebutuhan & $\begin{array}{c}\text { Kesesuaian } \\
\text { (Ya/Tidak/Belum) }\end{array}$ \\
\hline \multicolumn{3}{|c|}{ Kebutuhan fungsional } \\
\hline 1 & Sistem Kegiatan ini dibangun berbasis web & Ya \\
\hline 2 & $\begin{array}{l}\text { Sistem kegiatan ini dapat di input oleh beberapa } \\
\text { pengguna dalam hal ini staf unit kerja yang merupakan } \\
\text { pelaksana kegiatan }\end{array}$ & Ya \\
\hline 3 & $\begin{array}{l}\text { Sistem kegiatan ini dapat dilihat oleh seluruh sivitas } \\
\text { akademika Universitas Terbuka (pengguna) }\end{array}$ & Ya \\
\hline 4 & $\begin{array}{l}\text { Untuk memasukan data terhadap sistem dibutuhkan } \\
\text { login khususdari staf sivitas akademika, sedangkan } \\
\text { pengguna tidak perlu login. }\end{array}$ & Ya \\
\hline 5 & $\begin{array}{l}\text { Staf maupun pengguna dapat melihat laporan dari } \\
\text { seluruh kegiatan yang terjadi }\end{array}$ & Ya \\
\hline 6 & $\begin{array}{l}\text { Data kegiatan yang dimasukan adalah informasi } \\
\text { kegiatan, waktu dimulai, waktu selesai, tempat kegiatan, } \\
\text { nama kegiatan, unit penyelenggara, peserta dan staf } \\
\text { input. }\end{array}$ & Ya \\
\hline \multicolumn{3}{|c|}{ Kebutuhan non fungsional } \\
\hline 1 & Sistem ini berjalan di server apapun & Ya \\
\hline 2 & Sistem ini menggunakan bahasa pemograman web & Ya \\
\hline 3 & Sistem ini menggunakan database my sql & Ya \\
\hline 4 & $\begin{array}{l}\text { Dapat diakses oleh browser apapun dikomputer } \\
\text { pengguna }\end{array}$ & Ya \\
\hline
\end{tabular}

Dari tabel 1 dapat dilihat dari 6 komponen untuk kebutuhan fungsional dan 5 komponen 5 komponen untuk kebutuhan non fungsional. Dari komponen-komponen yang telah dianalisis tersebut semua komponen perancangan ini sudah memenuhi dengan 
kebutuhan hasil analisis. Oleh karena itu dapat disimpulkan kesesuaian perancangan ini adalah $100 \%$.

\section{KESIMPULAN}

Perancangan aplikasi dengan model terstuktur ini dapat dijadikan sebagai bahan dasar untuk ketahap berikutnya yaitu pembuatan aplikasi / koding menggunakan bahasa pemograman web. Rancangan yang telah dibangun mulai dari data flow diagram, diagram alur, rancangan database dan rancangan tampilan. Hasil dari perancangan sistem informasi ini $100 \%$ sudah dapat sesuai dengan kebutuhan sistem informasi manajemen kegiatan Universitas Terbuka sehingga untuk penelitian selanjutnya adalah implementasi atau pembuatan aplikasi sesuai dengan rancangan dari penelitian ini.

\section{REFERENSI}

[1] M. Ngafifi, "Kemajuan Teknologi Dan Pola Hidup Manusia Dalam Perspektif Sosial Budaya," J. Pembang. Pendidik. Fondasi dan Apl., vol. 2, no. 1, pp. 33-47, 2014.

[2] P. Anugeraha, "PERAN DAN FUNGSI TEKNOLOGI INFORMASI DALAM KEHIDUPAN SEHARI-HARI," 2017.

[3] E. Sutanta, "Jurnal_MANAJERIAL-DUKUNGAN_SISTEM_INFORM.pdf.” 2005.

[4] M. M. Oktavianto, Analisis dan Perancangan Sistem Informasi Menggunakan Model Terstruktur dan UML. 2016.

[5] A. Vera, "Pendekatan Perancangan Terstruktur Data Flow Diagram," pp. 1-20, 2014.

[6] M. Page-Jones, The practical guide to structured systems design: 2nd edition. 1988.

[7] G. A. F. Maulani, A. Suryadi, Y. Nugraha, N. A. Hamdani, and Y. Purwanti, "Web-based student master book information system in vocational school of Muhammadiyah Banyuresmi," J. Phys. Conf. Ser., vol. 1280, no. 3, 2019.

[8] A. Mahaseptiviana, A. B. Tjandrarini, and P. Sudarmaningtyas, "Analisa Perancangan Sistem Informasi Penjualan Air Minum Pada CV. Air Putih," JSINBIS (Jurnal Sist. Inf. Bisnis), vol. Vol.3 No., no. 2, pp. 157-165, 2014.

[9] W. Danto, A. Putri, and K. A. Laksitowening, "Analisis Kebutuhan Fungsional Sistem Informasi It Telkom," no. May 2014, 2011.

[10] R. Djajilah, "ANALISIS KEBUTUHAN NON FUNGSIONAL SUPERMARKET," 2018.

[11] R. M. Dennis, A., Wixom, B.H. and Roth, Systems Analysis and Design. 3rd, vol. 111, no. 479. 2006.

[12] R. Ibrahim and S. Y. Yen, "Formalization of the Data Flow Diagram Rules for Consistency Check," Int. J. Softw. Eng. Appl., vol. 1, no. 4, pp. 95-111, 2010.

[13] D. T. Octafian, "Desain database sistem informasi penjualan barang," J. Teknol. dan Inform., vol. 1, no. 2, pp. 148-157, 2013.

[14] F. S. Nugraha, F. H. Purwanto, Mayadi, M. Huda, M. M. Munir, and R. T. Puji, "Perancangan Antarmuka Sistem Pakar Penyakit Padi Berbasis Web Design for Expert System Interface of Web-Based Rice Disease,” J. Ilm. SISFOTENIKA, vol. 7, no. 2, pp. 143-154, 2017.

[15] F. Sulianta, NoIT ERgonomics - Menjadi sehat dan produktif dalam kantor berbasis teknologi informasi Title. 2010.

[16] Suryadi, "Perancangan Aplikasi Game Edukasi," J. PETIK, vol. 3, no. 32, pp. 8-13, 2017.

[17] Ian Sommerville, Software Engineering, 9th ed. 2011.

[18] B. Mikkelsen, Methods for Development Work and Research : A New Guide for Practitioners, 2nd ed. Yayasan Pustaka Obor Indonesia, 2011. 